\title{
First report of Curvularia tuberculata leaf spot on Archontophoenix alexandrae in Pakistan
}

\author{
Imran UI Haq ${ }^{1}$ - Siddra ljaz ${ }^{2}$ Anjum Faraz ${ }^{1} \cdot$ Nabeeha Aslam Khan ${ }^{1}$ \\ Received: 29 January 2020 / Accepted: 14 July 2020 / Published online: 20 July 2020 \\ (C) Società Italiana di Patologia Vegetale (S.I.Pa.V.) 2020
}

Keywords Perennial ornamental palm $\cdot$ Leaf spots $\cdot$ Morphological and Molecular identification

Archontophoenix alexandrae (F. Muell.) H. Wendl. \& Drude (Alexandra palm) is a perennial ornamental palm distributed in tropical and subtropical regions worldwide. Ovoid with chlorotic halos brown spots ranging from $9 \mathrm{~mm}$ to $2 \mathrm{~cm}$ in size scattered on leaves blades from margins to midrib were observed in Kasur and Faisalabad districts of Punjab, Pakistan with 56 and $43 \%$ disease incidence, respectively. Under severe conditions, spots enlarged and turned into necrotic lesions covering major leaf area. Symptomatic leaves tissues were cut, surface disinfected with $3 \%$ sodium hypochlorite solution for $30 \mathrm{~s}$, placed onto potato dextrose agar (PDA) culture medium and incubated at $28^{\circ} \mathrm{C}$ for $72 \mathrm{~h}$. Single hyphal tips were taken for fungal purification. Grayish to black septate branched hyphae with zonate sporulation, unbranched, geniculate conidiophores $(83-126 \mu \mathrm{m}$ in size) producing conidia straight to curved with 3-5 septations (16-34.5 × 11-13 $\mu \mathrm{m}$ in size) were observed (Ellis 1971). To confirm the morphological identification, the DNA of a reference isolate was sequenced. The sequences of three loci internal transcribed spacer (ITS), glyceraldehyde 3-phosphate dehydrogenase (GAPDH) and RNA polymerase II second largest subunit (RPB2) showed $100 \%$ similarity to strain of CBS 146.63 . These sequences were deposited to GenBank with following accession numbers MF448225, MN972616 and MN972617, respectively. Based on morphological and molecular analyses the reference isolate was identified as Curvularia tuberculata B. L. Jain. The reference isolate was deposited to Fungal Molecular Biology Culture Collection (FMB-CC-UAF) University of Agriculture Faisalabad, Pakistan with accession number FMB0005. To fulfill

Siddra Ijaz

siddraijazkhan@yahoo.com

1 Department of Plant Pathology, University of Agriculture Faisalabad, Faisalabad, Pakistan

2 Centre of Agricultural Biochemistry and Biotechnology, University of Agriculture Faisalabad, Faisalabad, Pakistan
Koch's postulates, a pathogenicity test was performed on sixmonth-old plants of A. alexandrae. Spore suspension of $1 \times 10^{5}$ spores/ml concentration was sprayed on young leaves, while sterile distilled water on control plants. After 7-10 days of incubation, symptoms were observed on leaves as during survey and C. tuberculata was confirmed as fungal pathogen by re-isolation. To our knowledge, this is the first report of C. tuberculata causing leaf spot on Alexandra palm in Pakistan and worldwide (Farr and Rossman 2020).

Funding information This study was funded by HEC Project \#2762

\section{Compliance with ethical standards}

Conflict of interest All authors declare that they have no conflict of interests.

Ethical statement This article does not contain any studies with human participants or animals.

\section{References}

Ellis MB (1971) Dematiaceous hyphomycetes. CMI, Kew

Farr DF, Rossman AY (2020) Fungal Databases, U.S. National Fungus Collections, ARS, USDA. Retrieved March 14, 2020.

Publisher's note Springer Nature remains neutral with regard to jurisdictional claims in published maps and institutional affiliations. 